\title{
Universities and \\ the Chinese Defense Technology Workforce
}

CSET Issue Brief

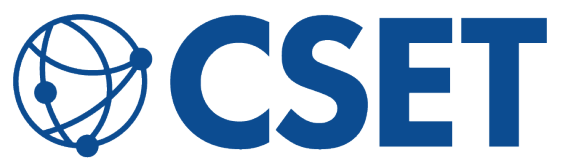

CENTER for SECURITY and EMERGING TECHNOLOGY
AUTHORS

Ryan Fedasiuk

Emily Weinstein 


\section{Table of Contents}

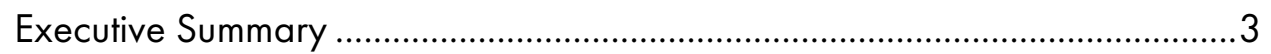

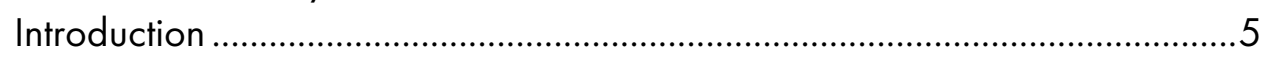

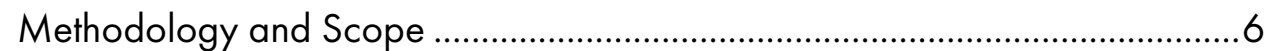

Part I: China's Defense Companies Recruit from Civilian Universities...............9

Part II: Some U.S. Tech Companies Indirectly Support China's Defense

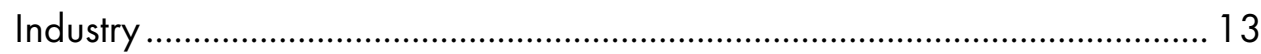

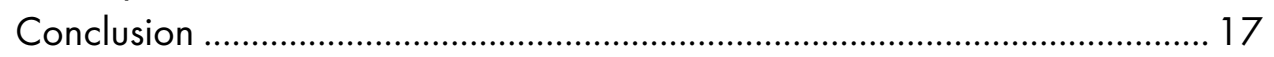

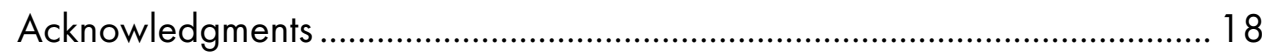

Appendix I: Chinese Universities Included in This Report ............................... 19

Appendix II: Breakdown by Employer .......................................................... 20

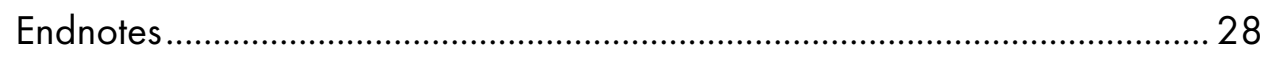




\section{Executive Summary}

Since the mid-2010s, U.S. lawmakers have voiced a broad range of concerns about academic collaboration with the People's Republic of China (PRC), but the most prominent have been about China's strategy of militarycivil fusion (MCF). One concern holds that Chinese university students or graduates may come to the United States on exchange programs or for postgraduate education, then return and contribute to China's military modernization. 'To address this concern, U.S. policymakers must first understand which forms of collaboration, and with which Chinese universities, pose the greatest risk to U.S. research security.

This report examines 2019 graduate employment data from 45 elite Chinese universities, in addition to Ministry of Education documents, which list collaborative training projects between private companies and Chinese universities. Key findings include the following:

- Chinese defense state-owned enterprises (SOEs) directly hired a combined 6,000 graduates from 29 leading Chinese universities in 2019.

- China's defense SOEs tend to recruit far more graduates completing advanced degree programs than those finishing baccalaureates.

China's "Seven Sons of National Defense" include the following universities:

- Beijing Institute of Technology

- Beijing University of Aeronautics and Astronautics

- Harbin Engineering University

- Harbin Institute of Technology

- Nanjing University of Aeronautics and

Astronautics

- Nanjing University of Science and Technology

- Northwestern Polytechnical University

- Three quarters of graduates recruited by defense SOEs come from China's "Seven Sons of National Defense," a group of universities administered directly by the Ministry of Industry and Information Technology.

- From 2018-2019,13 U.S. technology companies established collaborative training programs with the Seven Sons. These projects primarily involved training faculty and developing course curricula related to machine learning, big data, and integrated circuit design. 
- U.S. tech companies may inadvertently aid China's military modernization through their subsidiaries' relationships with defenseaffiliated universities.

Our findings confirm that the Seven Sons of National Defense are important feeders for China's military and defense industry. However, it appears that the vast majority of civilian universities in China maintain at least some connection to the country's defense industry.

Furthermore, despite the risks of collaborating with universities so closely tied to China's defense industrial base, we find that several prominent U.S. technology companies have established close working relationships with the Seven Sons and other defense affiliated universities in China. Documents from the Chinese Ministry of Education indicate that the Seven Sons have benefited from training programs and partnerships with the China-based subsidiaries or joint ventures of Autodesk, Dell, Google, Honeywell, IBM, Intel, Merrill Lynch, Microsoft, National Instruments, Rockwell Automation, Synopsys, Tektronix, and Texas Instruments. 


\section{Introduction}

In recent years, the U.S. government has sought to limit U.S. research institutions' exposure to China's defense industry. Despite mounting concerns around U.S.-China collaboration, however, U.S. policymakers recognize that placing blanket limitations on Chinese universities with any connections to the People's Liberation Army (PLA) would incur major costs for the U.S. research enterprise. ${ }^{2}$ The United States needs a targeted approach to research security. Recent policy decisions such as Presidential Proclamation 10043 have placed selective restrictions on Chinese students and researchers with clear ties to China's MCF strategy. ${ }^{3}$

U.S. policymakers and university administrators are asking which forms of engagement, and with which Chinese universities, may unwittingly aid in China's military modernization. To inform that question, this study highlights relationships between certain leading Chinese universities and the PRC defense industry, based on how many graduates they supply to defense SOEs. We find that a select group of universities, China's Seven Sons of National Defense, contribute the lion's share of new hires at Chinese defense SOEs. Beyond defense SOEs, Appendix I also details how many graduates joined the PLA, as well as the Chinese Academy of Engineering Physics (CAEP), China's leading nuclear weapons lab. 
Table 1. Chinese Universities with the Most 2019 Graduates Employed by Major Defense Companies

\begin{tabular}{|c|c|c|c|c|}
\hline Name & Name (Chinese) & $\begin{array}{c}\text { No. of } 2019 \text { Grads } \\
\text { Employed by Chinese } \\
\text { Defense SOEs }\end{array}$ & $\begin{array}{c}\text { Portion of Employed } \\
\text { Graduates Working at } \\
\text { Chinese Defense } \\
\text { Companies }\end{array}$ & $\begin{array}{c}\text { Member of } \\
\text { "Seven Sons of } \\
\text { National } \\
\text { Defense" }\end{array}$ \\
\hline Northwestern Polytechnical University & 西北工业大学 & 963 & $26 \%$ & Yes \\
\hline $\begin{array}{l}\text { Beijing University of Aeronautics and } \\
\text { Astronautics (Beihang University) }\end{array}$ & 北京航空航天大学 & 833 & $24 \%$ & Yes \\
\hline Beijing Institute of Technology & 北京理工大学 & 767 & $17 \%$ & Yes \\
\hline Harbin Engineering University & 哈尔滨工程大学 & 753 & $24 \%$ & Yes \\
\hline Harbin Institute of Technology & 哈尔滨工业大学 & 581 & $13 \%$ & Yes \\
\hline $\begin{array}{l}\text { Nanjing University of Science and } \\
\text { Technology }\end{array}$ & 南京理工大学 & 416 & $13 \%$ & Yes \\
\hline Xi'an Jiaotong University & 西安交通大学 & 241 & $6 \%$ & No \\
\hline Tianjin University & 天津大学 & 229 & $4 \%$ & No \\
\hline Dalian University of Technology & 大连理工大学 & 191 & $3 \%$ & No \\
\hline Shanghai Jiaotong University & 上海交通大学 & 153 & $3 \%$ & No \\
\hline Total: Top Ten Universities & & \multicolumn{3}{|c|}{$\begin{array}{c}\text { 5,127 graduates employed by } \\
\text { Chinese defense SOEs }\end{array}$} \\
\hline
\end{tabular}

Source: Chinese universities' 2019 employment quality reports.

\section{Methodology and Scope}

Universities in China publish yearly graduate employment quality reports (毕 业生就业质量报告), which detail how many of their graduates find jobs after graduation, and where. We looked at employment data published by a group of 45 leading universities: all 42 "Double First Class" (双一流) universities, and the remaining three Seven Sons of National Defense (国防 七子).

* We added Harbin Engineering University, Nanjing University of Aeronautics and Astronautics, and Nanjing University of Science and Technology, which are not considered Double First Class universities, but which are three of China's Seven Sons of National Defense. 
- Double First Class Universities are a group of 42 elite Chinese universities that the Chinese government believes have the potential to become world-class universities with world-class curricula (hence the name Double First Class). ${ }^{4}$ As a result of their status, these universities receive preferential treatment and access to greater resources from the Ministry of Education and Ministry of Finance. ${ }^{5}$

- The Seven Sons of National Defense are a group of seven universities with historical ties to China's defense industry. They are directly administered by the State Administration for Science,

Technology, and Industry for National Defense (国家国防科技工业 局; SASTIND), and their academic disciplines focus predominantly on science and technology with dual-use applications. Four of the Seven Sons-Northwestern Polytechnical University, Beijing University of Aeronautics and Astronautics, Beijing Institute of Technology, and Harbin Institute of Technology-are also considered Double First Class Universities.

A full list of the 45 universities considered in this report can be found in Appendix I. Of the 45 elite universities we considered for analysis, 29 published data detailing how many of their graduates went to work at specific companies. Collectively, these 29 universities produced 250,000 graduates in 2019, of whom 141,000 had secured post-graduation job contracts. This paper focuses on their career moves-specifically, how many took jobs at China's state-owned defense companies, outlined in Table 2.

Table 2. China's State-Owned Defense Companies

\begin{tabular}{|l|r|r|l|l|}
\hline Company & $\begin{array}{l}\text { Year } \\
\text { Established }\end{array}$ & $\begin{array}{l}\text { No. of } \\
\text { Employees }\end{array}$ & $\begin{array}{l}\text { Key Areas } \\
\text { Export } \\
\text { Contro/s? }\end{array}$ \\
\hline $\begin{array}{l}\text { Aero Engine Corporation of China } \\
\text { (AECC; 中国航空发动机集团) }\end{array}$ & $2016^{7}$ & $96,000^{8}$ & Aircraft engines and materials & No \\
\hline $\begin{array}{l}\text { Aviation Industry Corporation of China } \\
\text { (AVIC; 中国航空工业集团公司) }\end{array}$ & $\begin{array}{r}\text { reorganized in } \\
2008^{10}\end{array}$ & $450,000^{11}$ & $\begin{array}{l}\text { Aviation weapons and } \\
\text { equipment, military transport } \\
\text { aircraft, helicopters, airborne } \\
\text { systems, general aviation, } \\
\text { aviation R\&D }{ }^{12}\end{array}$ & Yes \\
\hline $\begin{array}{l}\text { China Aerospace Science and Industry } \\
\text { Corporation (CASIC; 中国航天科工集 } \\
\text { 才有限公司) }\end{array}$ & $2002^{13}$ & $150,000^{14}$ & $\begin{array}{l}\text { Aerospace defense, } \\
\text { commercial aerospace, } \\
\text { industrial internet, smart }\end{array}$ & Yes \\
\hline
\end{tabular}




\begin{tabular}{|c|c|c|c|c|}
\hline & & & industries $^{15}$ & \\
\hline $\begin{array}{l}\text { China Aerospace Science and } \\
\text { Technology Corporation (CASC; 中国 } \\
\text { 航天科技集团有限公司) }\end{array}$ & $1999^{16}$ & $180,000^{17}$ & $\begin{array}{l}\text { Aerospace products, } \\
\text { missile/weapons systems and } \\
\text { products }\end{array}$ & Yes \\
\hline $\begin{array}{l}\text { China Electronics Technology Group } \\
\text { (CETC; 中国电子科技集团) }\end{array}$ & $2002^{18}$ & $190,000^{19}$ & $\begin{array}{l}\text { Electronic equipment, } \\
\text { software, hardware } \\
\text { components }^{20}\end{array}$ & Yes \\
\hline $\begin{array}{l}\text { China National Nuclear Corporation } \\
\text { (CNNC; 中国核工业集团公司) }\end{array}$ & 1999 & $150,000^{21}$ & $\begin{array}{l}\text { Nuclear technologies, nuclear } \\
\text { energy }^{22}\end{array}$ & Yes \\
\hline $\begin{array}{l}\text { China North Industries Corporation } \\
\text { (NORINCO; 中国兵器工业集团公司) }\end{array}$ & $1999^{23}$ & $220,000^{24}$ & $\begin{array}{l}\text { Military technology, tanks and } \\
\text { armored vehicles, air and } \\
\text { missile defense }\end{array}$ & Yes \\
\hline $\begin{array}{l}\text { China Shipbuilding Industry Corporation } \\
\text { (CSIC; 中国船舶重工股份有限公司) }\end{array}$ & $1999^{26}$ & $165,000^{27}$ & $\begin{array}{l}\text { Ship R\&D, ship design and } \\
\text { manufacturing, marine defense } \\
\text { and transportation equipment, } \\
\text { deep-sea equipment }\end{array}$ & No \\
\hline $\begin{array}{l}\text { China South Industries Group } \\
\text { Corporation (CSGC; 中国南方工业集 } \\
\text { 团公司) }\end{array}$ & 1999 & 170,000 & $\begin{array}{l}\text { Firearms, vehicle parts, and } \\
\text { optical-electronic devices }\end{array}$ & No \\
\hline $\begin{array}{l}\text { China State Shipbuilding Corporation } \\
\text { (CSSC; 中国船舶集团有限公司) }\end{array}$ & $1982^{28}$ & $310,000^{29}$ & $\begin{array}{l}\text { Naval weapons and } \\
\text { equipment } R \& D \text {, production, } \\
\text { testing, and support }{ }^{30}\end{array}$ & No \\
\hline $\begin{array}{l}\text { Commercial Aircraft Corporation of } \\
\text { China (COMAC; 中国商用飞机有限 } \\
\text { 责任公司) }\end{array}$ & $2008^{31}$ & $11,000^{32}$ & $\begin{array}{l}\text { Large aircraft manufacturing } \\
\text { and } R \& D^{33}\end{array}$ & No \\
\hline
\end{tabular}

Note that for some companies, only a subsidiary is subject to U.S. export controls.

${ }^{\dagger} \mathrm{CSIC}$ and CSSC merged in 2019 to form the new China State Shipbuilding Corporation. ${ }^{34}$

The findings of this study are limited in several ways. First, our findings are restricted to the 29 universities for which data was available. Adding data from the missing 16 elite universities could change our results; any of the excluded universities may disproportionately produce graduates who work in the defense industry. Second, this report only assesses graduate flows from 2019 ; it is not clear to what extent this 2019 snapshot reflects longer-term employment trends in China. Third, Chinese universities highlight their employment data in different ways; some include every company that employs more than 10 graduates, or only the top 25 or 50 employers. Therefore, we do not know exactly how many students took jobs at each company discussed below. Finally, this analysis does not account for 
alternative career paths into China's defense industry. Students could pursue advanced degrees and be hired as professors at defense-affiliated universities, or enter private companies that contract with the PLA, and our analysis would not capture these inroads to China's defense industry. Despite these limitations, our findings establish a floor for universities' graduate flows, and highlight clear relationships between certain Chinese defense companies and the universities that feed them.

Moreover, this study does not tell a complete story. Using our approach, foreign observers of the United States could describe U.S. universities like Carnegie Mellon, the University of Arizona, or Georgia Tech as "defenseaffiliated" because their graduates frequently take jobs at Honeywell, Lockheed Martin, or Raytheon. ${ }^{35}$ To be sure, there are fundamental differences between the U.S. and Chinese higher education systems, and U.S. defense companies are not state-owned. But policymakers should carefully consider the political and scientific costs and benefits of labeling certain universities as "defense-affiliated."

\section{Part I: China's Defense Companies Recruit from Civilian} Universities

Chinese state-owned defense firms directly hired a combined 6,000 graduates from 29 leading Chinese universities in 2019-a 0.3 percent increase over their estimated 2018 workforce of 2.1 million people. Nearly two-thirds of graduates bound for the defense industry $(3,725$ people) took jobs at the three largest state-owned electronics and aerospace companies: China Electronics Technology Group (CETC), Aviation Industry Corporation of China (AVIC), and China Aerospace Science and Technology Corporation (CASC).

Table 3. Chinese Defense SOEs' New Hires (2019) from Leading Chinese Universities

\begin{tabular}{|l|r|}
\hline \multicolumn{1}{|c|}{ Name } & $\begin{array}{c}\text { No. of 2019 Elite University } \\
\text { Grads Employed }\end{array}$ \\
\hline China Electronics Technology Group (CETC) & 1,370 \\
\hline Aviation Industry Corporation of China (AVIC) & 1,210 \\
\hline China Aerospace Science and Technology Corporation (CASC) & 1,145 \\
\hline
\end{tabular}




\begin{tabular}{|l|r|}
\hline China Aerospace Science and Industry Corporation (CASIC) & 697 \\
\hline China Shipbuilding Industry Corporation (CSIC) & 322 \\
\hline China North Industries Corporation (NORINCO) & 318 \\
\hline Commercial Aircraft Corporation of China (COMAC) & 280 \\
\hline China National Nuclear Corporation (CNNC) & 209 \\
\hline China State Shipbuilding Corporation (CSSC) & 177 \\
\hline Aero Engine Corporation of China (AECC) & 87 \\
\hline China South Industries Group Corporation (CSGC) & 5,979 \\
\hline Total: Al/ Eleven Defense Companies & \\
\hline
\end{tabular}

Source: Chinese universities' 2019 employment quality reports.

There are several notable trends in the way China's state-owned defense companies recruit recent university graduates.

First, China's defense giants recruit primarily from a small group of elite universities. Nearly every leading Chinese university produces some graduates who take jobs in China's defense industry. However, of the 10 universities that produce the most defense industry employees, six are members of China's "Seven Sons of National Defense" - the seventh "Son" being Nanjing University of Aeronautics and Astronautics (南京航空航天大 学), for which data was not available. Collectively, these six universities produced just 16 percent of the employed graduates in our dataset, but 72 percent of the graduates who took jobs at major defense companies. By comparison, the next four universities-Xi'an Jiaotong University, Tianjin University, Dalian University of Technology, and Shanghai Jiaotong University-generated 11 percent of the employed graduates in our dataset, and 14 percent of new defense company hires.

Second, China's defense companies tend to recruit far more graduates with advanced degrees than they do undergraduate degree holders. Few universities disaggregate their employment data in a way that would allow us to measure this trend comprehensively, but there are some notable examples. At Beijing University of Aeronautics and Astronautics, just eight percent of graduates hired by defense companies had completed only their undergraduate degrees; the remaining 92 percent had completed graduate 
degree programs. ${ }^{36}$ The same is true at Harbin Engineering University and at Tianjin University, where undergraduates represented more than half of all graduating students, but fewer than a quarter of those who took jobs at defense companies. ${ }^{37}$

Third, we found several instances where a Chinese university had established an especially close relationship with one or more defense companies. Three universities have especially close relationships with defense SOEs; other relationships are explored in Appendix II:

- Northwestern Polytechnical University (NWPU) and Aviation Industry Corporation of China (AVIC). NWPU is the top generator of new employees at China's largest defense company. The university has established a scholarship program specifically for students looking to work at AVIC, and generated more than a quarter of all elite university graduates $\mathrm{AVIC}$ recruited in 2019.

- Harbin Engineering University (HEU) and China Shipbuilding Industry Corporation (CSIC). HEU was established as a shipbuilding institute in the 1970s, and today maintains strong connections to China's shipbuilding industry. More than half of the elite university graduates CSIC recruited in 2019 came from HEU.

- Beijing Institute of Technology (BIT) and China North Industries Corporation (NORINCO). BIT is consistently among the top feeder schools of many large defense companies, but it holds a particularly important place for NORINCO, for whom it is the top source of new employees. BIT and NORINCO have signed several strategic cooperation agreements and hold exclusive job fairs. Although NORINCO has been on the U.S. Department of Commerce's Bureau of Industry and Security Entity List since 2003, BIT is not. ${ }^{38}$

Figure 1 illustrates relationships between universities in China and the defense companies they feed. The vertical size of each box indicates the number of graduates (for universities to the left) or new hires (for companies to the right) in 2019. The strongest relationships are between NWPU, BUAA (Beihang University), BIT, and HEU; and AVIC, CASC, CASIC, and CSIC, respectively. 
Figure 1. 2019 Graduate Flows Between Chinese Universities and Chinese Defense SOEs

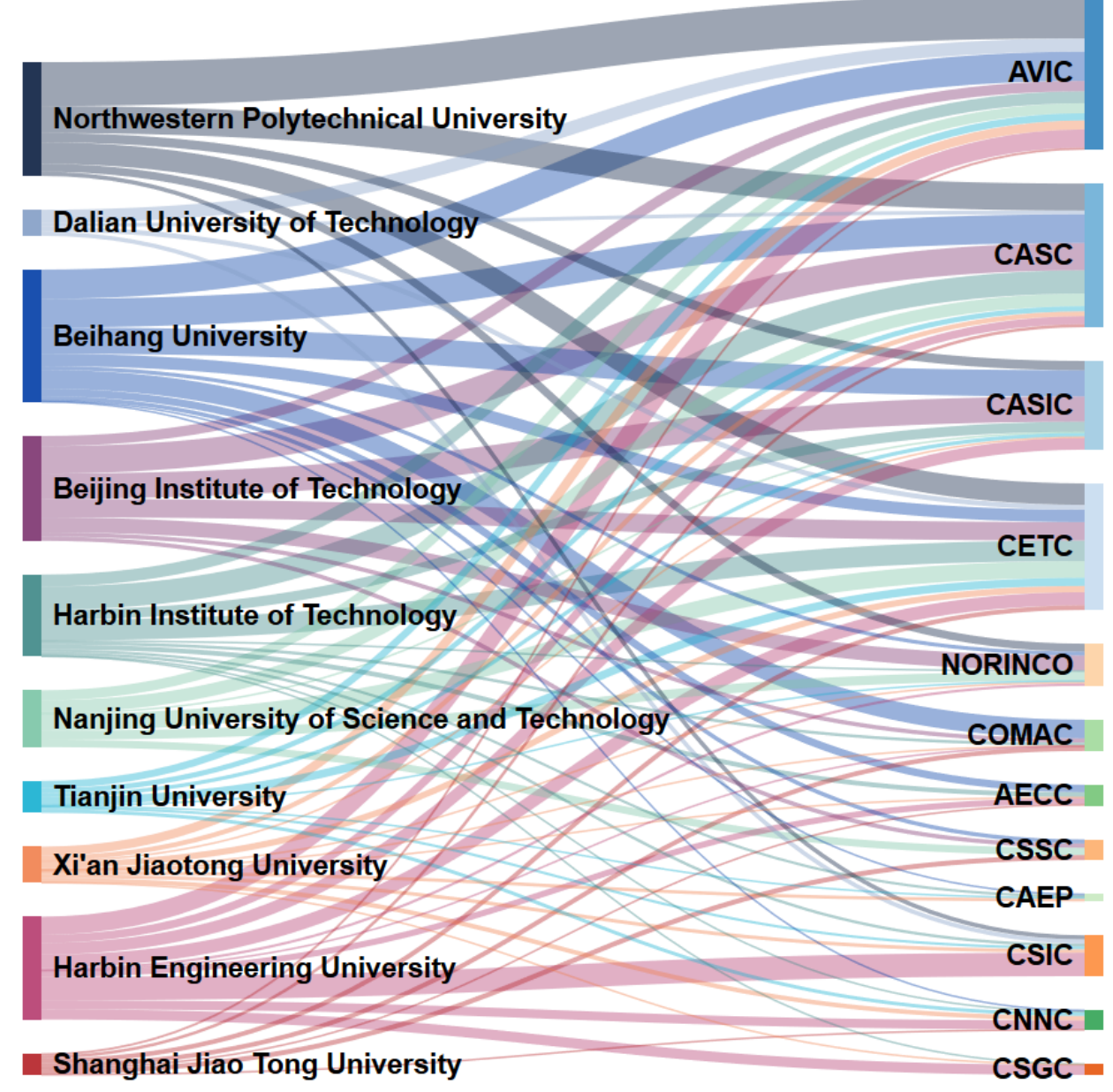

Finally, in addition to the Seven Sons of National Defense-which have clear connections to the military-we find that several students from civilian universities like Dalian University of Technology, Xi'an Jiaotong University, Tianjin University, and Shanghai Jiaotong University took jobs at defense SOEs in 2019. Many, if not all, civilian Chinese universities maintain at least some connection to China's defense apparatus. ${ }^{39}$ For example, the Dalian University of Technology in 2004 jointly established the National Defense

* It is difficult to estimate how many graduates at any given Chinese university will enter the defense industry. At half of the universities we examined, more than 3 percent of employed graduates (between 50 and 1,000 people) went to work for state-owned defense companies. At the other half, fewer than 1 percent (fewer than 50 people) did so. 
Education College (大连理工大学国防教育学院) with the Shenyang Military Region (now the Northern Theater Command) to "cultivate new military talents for national defense." 40 The project included hiring PLA generals as faculty members at the university. ${ }^{41}$ Similarly, Tianjin University, which was named an "Advanced Unit of National Defense Education" (国防 教育先进单位) by the local PLA branch in Nankai, ${ }^{42}$ maintains a joint research institute on human-computer interaction with the PLA Academy of Military Science. ${ }^{43}$ These are just two examples, but it is likely that the majority of top universities in China have some observable connection to the defense industry or the PLA. The extent of these relationships requires further analysis beyond the scope of this report.

\section{Part II: Some U.S. Tech Companies Indirectly Support China's Defense Industry}

The findings of this report imply that seven universities-China's Seven Sons of National Defense-are particularly important feeders for China's military and defense industry. Collectively, they produce nearly three quarters of the elite university graduates hired by China's largest defense companies. Despite the risks associated with collaborating with these institutions, we find that several U.S. technology companies have established and maintain close working relationships with the Seven Sons and other defense-affiliated universities in China. $^{44}$

Specifically, we counted 42 cases where U.S. companies and their subsidiaries have trained faculty members at China's Seven Sons of National Defense; ${ }^{45}$ developed course curricula related to computer science and integrated circuit design, ${ }^{46}$ constructed new laboratory facilities, or furnished them with equipment. ${ }^{47}$ Considering the number of graduates from these universities who take jobs in China's defense industry, it is likely that U.S. tech companies are inadvertently aiding in China's military modernization by providing resources and information to the next generation of China's defense industry engineers. 
Figure 2. No. of U.S. Tech Companies' Cooperative Training Projects Established with Chinese Universities (2018-2019)
Figure 3. No. of Chinese Universities' Graduates who Took Jobs at Chinese Defense Companies (2019)

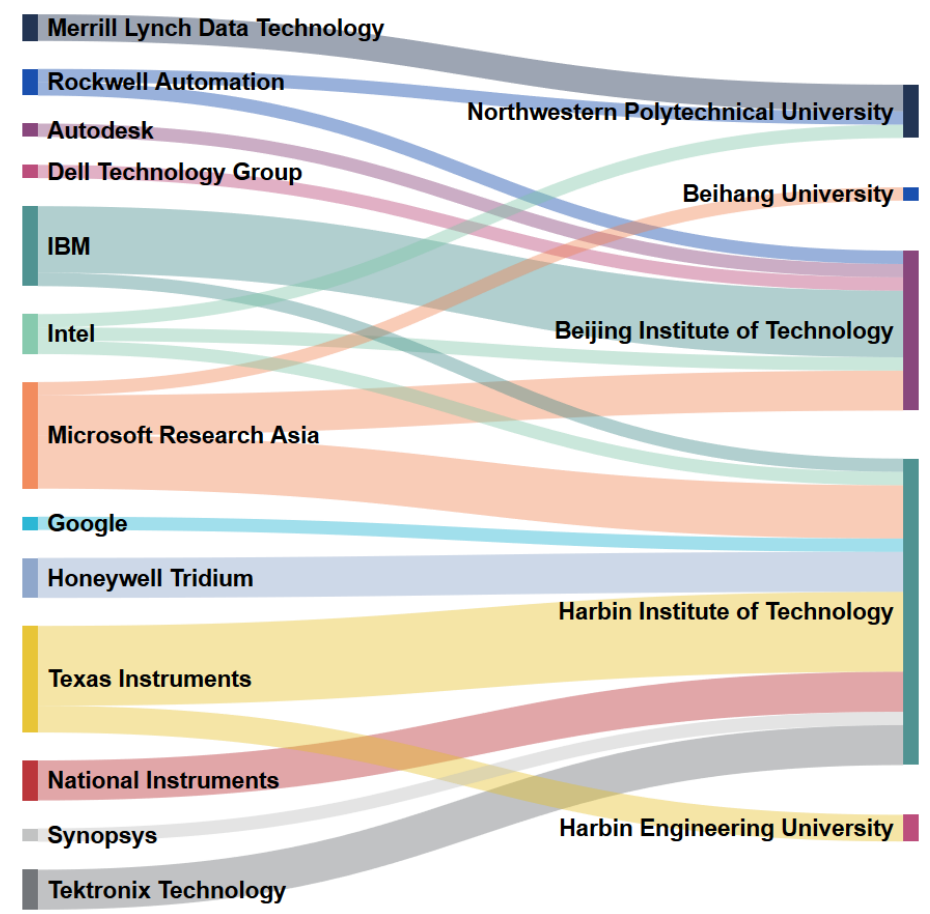

Source: 42 cooperative training programs published by the Ministry of Education, 2018-2019.

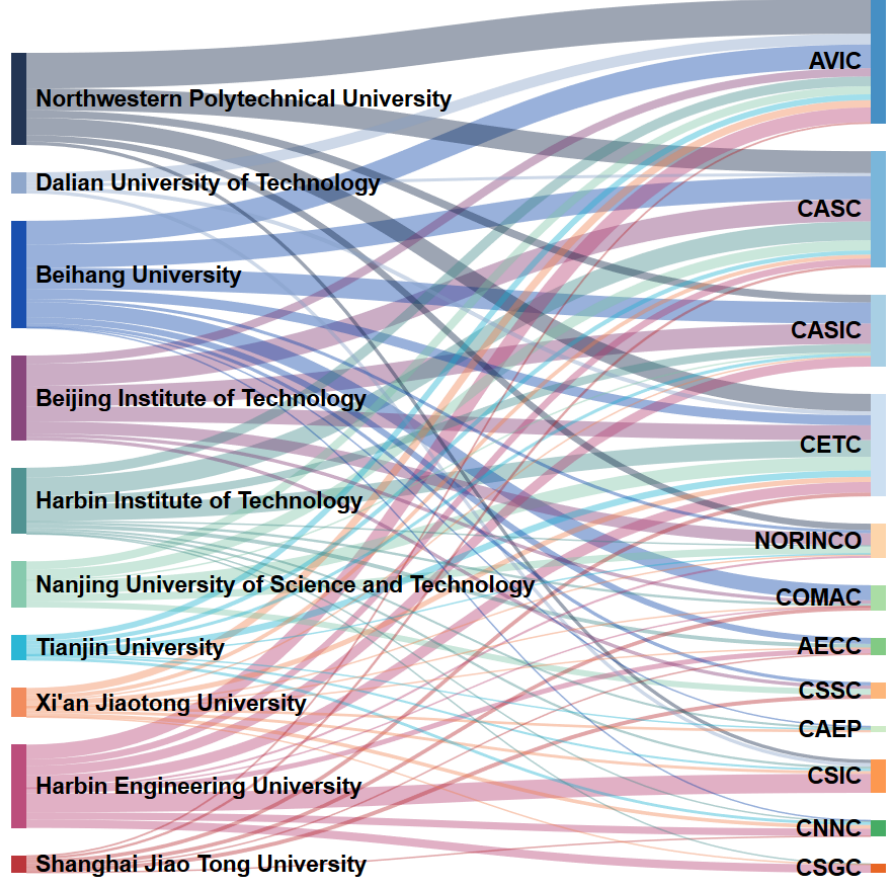

Source: 4,769 graduates' career paths published in 2019 graduate employment quality reports.

For private companies, collaboration with local research institutions is often the price of doing business in China. Many U.S. companies fear they will lose market access or face regulatory reprisal unless they comply with PRC government and Communist Party policies, including coerced technology transfer. ${ }^{48}$ One such policy is the Ministry of Education's charge to promote "industry-university cooperation and collaborative education projects" (产学 合作协同育人项目), whereby the MOE calls upon private enterprises, especially foreign companies' China-based subsidiaries and joint ventures, ${ }^{49}$ to aid in Chinese universities' research, curriculum development, and teacher training. ${ }^{50}$ Since 2006, China's National Medium and Long-term Education Reform and Development Plan has sought to "encourage multinational corporations to establish their R\&D centers in our country. ${ }^{51}$ In 2014, MOE 
formalized a "matchmaking" process to recommend collaborative projects between specific multinational companies and Chinese universities, including the Seven Sons. ${ }^{52}$

We canvassed the lists of "industry-university collaborative education projects" published by the Chinese MOE in 2018 and $2019 . .^{53}$ In those two years, MOE documents indicate that the China-based subsidiaries or joint ventures of 13 U.S. technology companies established training programs with China's Seven Sons of National Defense. These companies include Autodesk, Dell, Google, Honeywell, IBM, Intel, Merrill Lynch, Microsoft, National Instruments, Rockwell Automation, Synopsys, Tektronix, and Texas Instruments. We have not been able to confirm that every one of these companies actually established the training programs indicated by the Chinese government. However, we have been able to find corroborating information about several projects in news articles and on university and company websites. Below, we present three examples:

- IBM China and Beijing Institute of Technology signed a contract to build the IBM-BIT Mainframe Excellence Center (北理工一IBM 主机 卓越中心) in 2014. ${ }^{54}$ According to BIT, under the agreement, IBM would jointly build the facility and "provide our school with the worldclass mainframe IBM System z 10 enterprise server (z10 EC) for free. ${ }^{55}$ MOE documents indicate that in 2018, IBM launched a follow-up training program at BIT titled "Artificial intelligence for mainframe operation and management" (大型机操作和管理的人 工智能). A Sohu post from IBM China that year insisted that "As an advocate of the Ministry of Education's 'new engineering' construction, IBM has actively participated in it from the beginning," and said the company would launch 84 online technical courses for students at a coalition of universities that included BIT. ${ }^{56}$ The courses are related to quantum computing, artificial intelligence, and cognitive computing, among other topics. ${ }^{57}$ In 2019 , BIT was one of just eight universities partnering with IBM. ${ }^{58} \mathrm{~A}$ statement on the company's website reads, "We cherish the long-term love and support given to IBM by the Ministry of Education and partner universities, and will continue to support the reform and development of China's education industry." 59

- Microsoft Research Asia and Harbin Institute of Technology jointly launched the MSRA-HIT Artificial Intelligence and Machine Translation Joint Laboratory (哈工大一微软机器翻译技术联合实验 室) in 2000. ${ }^{60}$ By 2006, the Chinese Ministry of Education classified 
it as one of the country's Key Laboratories. ${ }^{61} \mathrm{HIT}^{\prime}$ s website indicates the lab is jointly financed by MOE and Microsoft Research Asia, and carries out research projects on behalf of the National Natural Science Foundation of China. ${ }^{62}$ In the course of its operations, the lab employs 120 HIT graduate students. ${ }^{63}$ It is unclear which HIT students may have trained in the lab during their studies, but university-wide data indicates that at least 14 percent of HIT graduate students entered the Chinese defense industry upon graduation in 2019. ${ }^{64}$ MOE documents also indicate that MSRA aided in developing computer science curricula and provided teacher training sessions related to artificial intelligence and natural language processing for HIT faculty in 2018 and 2019..$^{65}$ On its website, Microsoft Research Asia confirms it launched cooperative training programs with at least four of the Seven Sons. ${ }^{66}$

- Texas Instruments and Harbin Engineering University established the TI-HEU "Pocket Laboratory" Innovation Base (哈尔滨工程大学 与美国德州仪器口袋实验室) in 2015. ${ }^{67}$ The project constructed an equipment sharing system, whereby HEU students could borrow advanced TI processors to run computationally demanding programs from the comfort of their classrooms or dormitories. ${ }^{68}$ More recent MOE data indicates that in 2018 and 2019, TI aided HEU staff in developing curricula for courses on integrated circuit design. ${ }^{69}$

Figure 4. Texas Instruments and Harbin Engineering University Launch the "Pocket Laboratory" Innovation Base

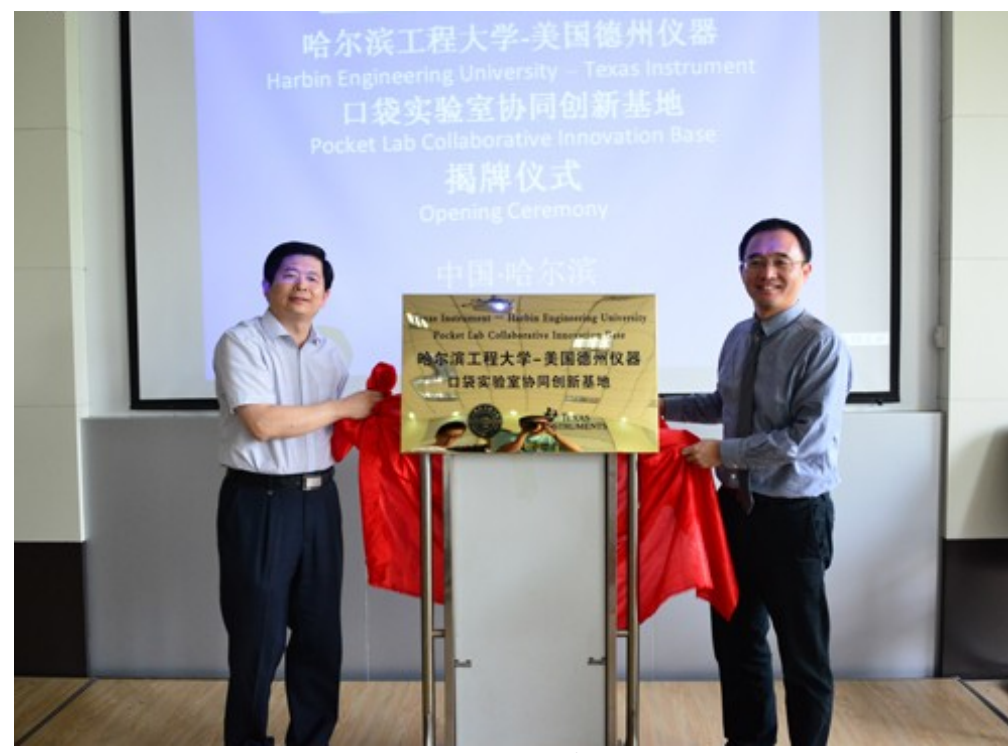

Source: Harbin Engineering University. ${ }^{70}$ 


\section{Conclusion}

The evidence presented in this report suggests a significant and meaningful relationship between the Seven Sons of National Defense and China's largest state-owned defense companies. Despite the risks posed by research collaboration, however, U.S. technology companies' China-based subsidiaries and joint ventures have established collaborative training projects with most of these universities. As a result, U.S. tech companies may inadvertently aid in China's military modernization. Beyond training students who end up working in the PRC defense industry after graduation, U.S. tech companies' participation in MOE-sponsored collaborative training projects may indirectly enhance or accelerate the Seven Sons' research into technologies with dual-use applications. Because the technical knowledge U.S. companies provide in these exchanges is not easily controllable, there is little way of ensuring it does not proliferate across China's wider defense industry after students graduate.

To protect its edge in innovation while incurring the least cost for its research enterprise, the United States should continue to focus on managing U.S. institutions' exposure to the Seven Sons and, by extension, China's defense industry. Several U.S. policies have addressed threats to U.S. research security, including Presidential Proclamation 10043, the publication of Chinese military-linked companies operating in the United States, ${ }^{71}$ and legislation aimed at addressing PRC government influence in higher education. ${ }^{72}$

Beyond the Seven Sons, the departments of several leading, ostensibly civilian Chinese universities require their researchers to hold advanced security credentials, receive funding from China's Ministry of State Security, or contribute directly to PLA-led research projects. ${ }^{73}$ The difficulty for the United States is that many of those universities are also some of the most advanced and well-funded in the world, and contribute countless personyears of expertise to the U.S. science and technology enterprise through their partnerships with U.S. companies and universities. ${ }^{74}$ Moving forward, it will be crucial for policymakers to find a way to balance the risks to research security and the benefits that come from engagement with China's civilian universities. 


\section{Acknowledgments}

The authors would like to thank Dakota Cary, Shelton Fitch, Igor MikolicTorreira, Dewey Murdick, Ben Murphy, Anna Puglisi, Lynne Weil, and Remco Zwetsloot for their suggestions on style and content. They are especially grateful to Tai Ming Cheung, Scott Harold, and Glenn Tiffert for their comprehensive reviews. Ben Murphy translated key documents, and Rebecca Gelles aided in graphic design. The authors are solely responsible for any errors.

\section{(c) (i) (8)}

(c) 2020 by the Center for Security and Emerging Technology. This work is licensed under a Creative Commons Attribution-Non Commercial 4.0 International License.

To view a copy of this license, visit https://creativecommons.org/licenses/by-nc/4.0/. 


\section{Appendix I: Chinese Universities Included in This Report}

This appendix includes all 45 "elite" Chinese universities considered in this report, and details which 29 published disaggregated employment information. We considered all 42 "Double First Class" universities, plus three universities that are not considered Double First Class, but which are members of China's Seven Sons of National Defense. "Class A" universities are institutions the Ministry of Education considers to be well on their way to becoming world-class universities; "Class B" institutions at least have the potential to do so. ${ }^{75}$

\begin{tabular}{|c|c|c|c|}
\hline Name (English) & Name (Chinese) & $\begin{array}{l}\text { Type of } \\
\text { University }\end{array}$ & $\begin{array}{l}\text { Disaggregated Employer } \\
\text { Data Available? }\end{array}$ \\
\hline Beijing Institute of Technology & 北京理工大学 & Class A & Yes \\
\hline Beiijing Normal University & 北京师范大学 & Class A & No \\
\hline $\begin{array}{l}\text { Beijing University of Aeronautics and Astronautics } \\
\text { (Beihang University) }\end{array}$ & 北京航空航天大学 & Class A & Yes \\
\hline Central South University & 中南大学 & Class A & Yes \\
\hline China Agricultural University & 中国农业大学 & Class A & No \\
\hline Chongqing University & 重庆大学 & Class A & Yes \\
\hline Dalian University of Technology & 大连理工大学 & Class A & Yes \\
\hline East China Normal University & 华东师范大学 & Class A & Yes \\
\hline Fudan University & 复旦大学 & Class A & Yes \\
\hline Harbin Engineering University & 哈尔滨工程大学 & Not DFC & Yes \\
\hline Harbin Institute of Technology & 哈尔滨工业大学 & Class A & Yes \\
\hline Huazhong University of Science \& Technology & 华中科技大学 & Class A & Yes \\
\hline Hunan University & 湖南大学 & Class B & Yes \\
\hline Jilin University & 吉林大学 & Class A & Yes \\
\hline Lanzhou University & 兰州大学 & Class A & Yes \\
\hline Minzu University of China & 中央民族大学 & Class A & No \\
\hline Nanjing University & 南京大学 & Class A & Yes \\
\hline $\begin{array}{l}\text { Naniing University of Aeronautics and } \\
\text { Astronautics }\end{array}$ & 南京航空航天大学 & Not DFC & No \\
\hline Nanjing University of Science and Technology & 南京理工大学 & Not DFC & Yes \\
\hline Nankai University & 南开大学 & Class A & Yes \\
\hline National University of Defense Technology & 国防科技大学 & Class A & No \\
\hline
\end{tabular}




\begin{tabular}{|c|c|c|c|}
\hline Northeastern University & 东北大学 & Class B & No \\
\hline $\begin{array}{l}\text { Northwest Agriculture \& Forestry Technology } \\
\text { University }\end{array}$ & 西北农林科技大学 & Class B & No \\
\hline Northwestern Polytechnical University & 西北工业大学 & Class A & Yes \\
\hline Ocean University of China & 中国海洋大学 & Class A & No \\
\hline Peking University & 北京大学 & Class A & Yes \\
\hline Renmin University & 中国人民大学 & Class A & No \\
\hline Shandong University & 山东大学 & Class A & Yes \\
\hline Shanghai Jiaotong University & 上海交通大学 & Class A & Yes \\
\hline Sichuan University & 四川大学 & Class A & No \\
\hline South China University of Technology & 华南理工大学 & Class A & No \\
\hline Southeast University & 东南大学 & Class A & Yes \\
\hline Sun Yat-sen University & 中山大学 & Class A & No \\
\hline Tianjin University & 天津大学 & Class A & Yes \\
\hline Tongii University & 同济大学 & Class A & Yes \\
\hline Tsinghua University & 清华大学 & Class A & Yes \\
\hline $\begin{array}{l}\text { University of Electronic Science \& Technology of } \\
\text { China }\end{array}$ & 电子科技大学 & Class A & No \\
\hline University of Science and Technology of China & 中国科学技术大学 & Class A & Yes \\
\hline Wuhan University & 武汉大学 & Class A & Yes \\
\hline Xi'an Jiaotong University & 西安交通大学 & Class A & Yes \\
\hline Xiamen University & 厦门大学 & Class A & Yes \\
\hline Xiniiang University & 新疆大学 & Class B & No \\
\hline Yunnan University & 云南大学 & Class B & No \\
\hline Zhejiang University & 浙江大学 & Class A & Yes \\
\hline Zhengzhou University & 郑州大学 & Class B & No \\
\hline
\end{tabular}

Appendix II: Breakdown by Employer

This appendix includes disaggregated recruitment data for Chinese defense SOEs mentioned in this report. Although beyond the scope of our analysis, we also include information about how many university graduates joined the PLA directly or went to work for the China Academy of Engineering Physics, China's leading nuclear weapons lab. 


\begin{tabular}{|c|c|c|c|}
\hline \multirow{2}{*}{$\begin{array}{l}\text { At least } 164 \text { graduates from leading Chinese universities took } \\
\text { jobs at AECC in } 2019 . \text { Among our sample, } 154 \text { employees } \\
\text { (93 percent) came from six universities, the largest being } \\
\text { Beihang University, which makes up } 34 \text { percent of total } \\
\text { graduates employed by AECC in } 2019 .\end{array}$} & University & $\begin{array}{l}\text { No. of } 2019 \\
\text { Graduates } \\
\text { Recruited by } \\
\text { AECC }\end{array}$ & $\begin{array}{l}\text { Portion of All } \\
\text { Employed } \\
\text { Graduates } \\
\text { Working at } \\
\text { AECC }\end{array}$ \\
\hline & $\begin{array}{l}\text { Beihang } \\
\text { University }\end{array}$ & 55 & $1 \%$ \\
\hline \multirow{4}{*}{$\begin{array}{l}\text { Beihang University and AECC appear to maintain a close } \\
\text { working relationship. Two Beihang alumni, Cao Jianguo and Li } \\
\text { Fangyong, were named, respectively, as the first chairman and } \\
\text { general manager of AECC when it was founded in } 2016 .^{76} \\
\text { Beihang's Research Institute for Aero Engine (航空发动机研 } \\
\text { 究院) houses two institutes-the Beihang Aviation Engine } \\
\text { Research Institute (北航航空发动机研究院) and the Aero } \\
\text { Engine International Academy (航空发动机国际学院), which } \\
\text { were co-founded by Beihang University and AECC in 2018. }\end{array}$} & \begin{tabular}{|l} 
Harbin \\
Engineering \\
University
\end{tabular} & 45 & $1 \%$ \\
\hline & $\begin{array}{l}\text { Harbin Institute } \\
\text { of Technology }\end{array}$ & 35 & $<1 \%$ \\
\hline & $\begin{array}{l}\text { Shanghai } \\
\text { Jiaotong } \\
\text { University }\end{array}$ & 11 & $<1 \%$ \\
\hline & $\begin{array}{l}\text { Huazhong } \\
\text { University of } \\
\text { Science and } \\
\text { Technology }\end{array}$ & 8 & $<1 \%$ \\
\hline
\end{tabular}

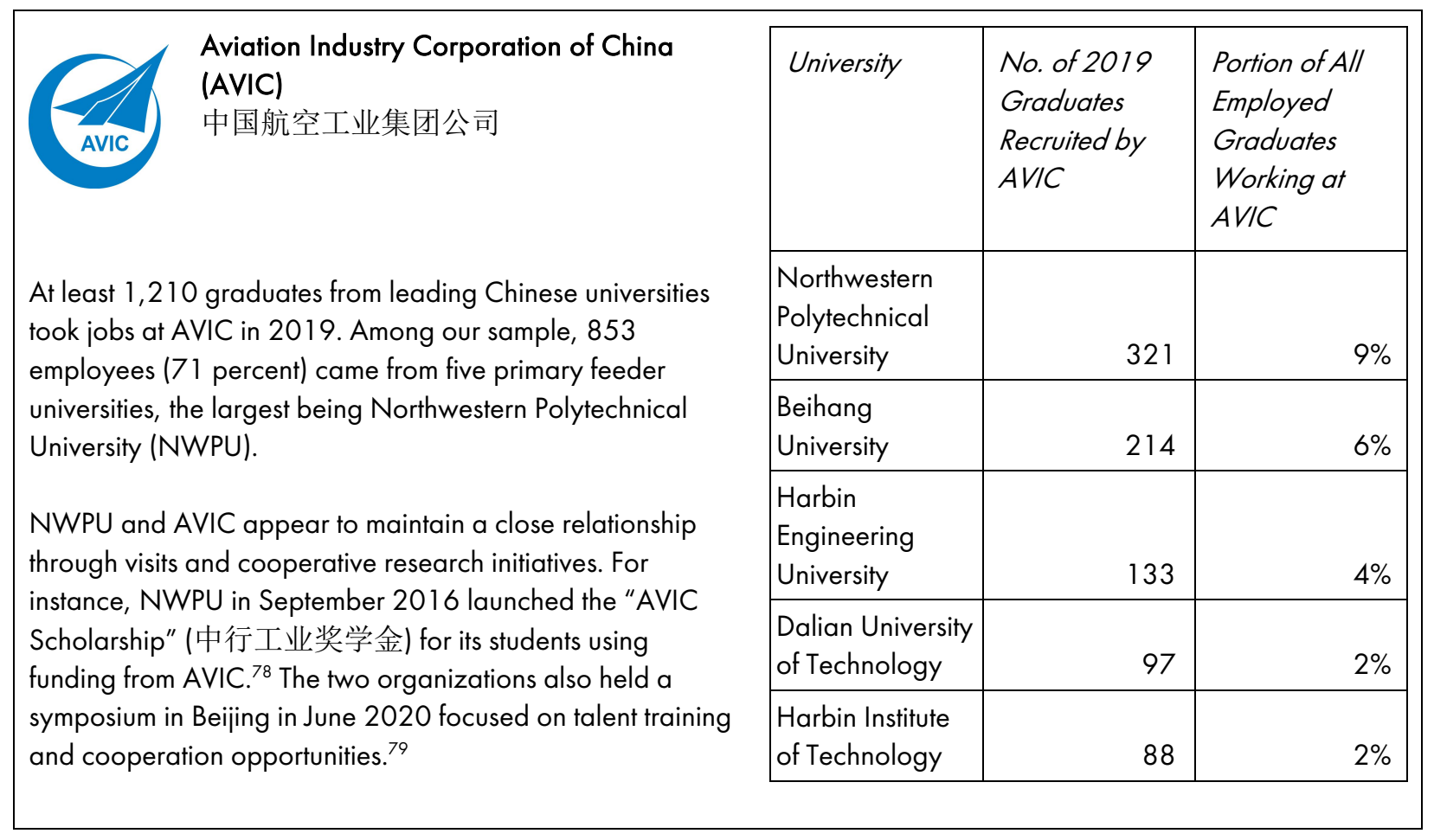




\section{China Aerospace Science and \\ COSIC Industry Corporation (CASIC) 中国航天科工集团有限公司}

At least 697 graduates from leading Chinese universities took jobs at CASIC in 2019. Available data indicates that 604 employees ( 87 percent) came from five primary feeder universities, the largest being Beihang University.

Beihang's School of Aeronautic Science and Engineering in 2012 signed and inaugurated the "Missile Aeroelastic Technology Joint Laboratory" with CASIC's Second Research Institute. A report from the inauguration ceremony states that the CASIC's Second Institute is "a national key military enterprise" (国家重点军工企业), and that Beihang has unique advantages in aeroelastic research and has made significant contributions to CASIC's weapons and equipment construction. $^{80}$

\begin{tabular}{|c|c|c|}
\hline University & $\begin{array}{l}\text { No. of } 2019 \\
\text { Graduates } \\
\text { Recruited by } \\
\text { CASIC }\end{array}$ & $\begin{array}{l}\text { Portion of All } \\
\text { Employed } \\
\text { Graduates } \\
\text { Working at } \\
\text { CASIC }\end{array}$ \\
\hline $\begin{array}{l}\text { Beihang } \\
\text { University }\end{array}$ & 192 & $6 \%$ \\
\hline $\begin{array}{l}\text { Beiijing Institute } \\
\text { of Technology }\end{array}$ & 185 & $4 \%$ \\
\hline $\begin{array}{l}\text { Harbin } \\
\text { Engineering } \\
\text { University }\end{array}$ & 86 & $3 \%$ \\
\hline $\begin{array}{l}\text { Harbin Institute } \\
\text { of Technology }\end{array}$ & 73 & $2 \%$ \\
\hline $\begin{array}{l}\text { Northwestern } \\
\text { Polytechnical } \\
\text { University }\end{array}$ & 68 & $2 \%$ \\
\hline
\end{tabular}

\begin{tabular}{|c|c|c|c|}
\hline $\begin{array}{l}\text { China Aerospace Science and Technology } \\
\text { Corporation (CASC) } \\
\text { 中国航天科技集团有限公司 }\end{array}$ & University & $\begin{array}{l}\text { No. of } 2019 \\
\text { Graduates } \\
\text { Recruited by } \\
\text { CASC }\end{array}$ & $\begin{array}{l}\text { Portion of All } \\
\text { Employed } \\
\text { Graduates } \\
\text { Working at } \\
\text { CASC }\end{array}$ \\
\hline \multirow{2}{*}{$\begin{array}{l}\text { At least 1, } 145 \text { graduates from leading Chinese universities } \\
\text { took jobs at CASC in } 2019 \text {. Available data indicates that } \\
870 \text { employees ( } 76 \text { percent) came from five primary feeder } \\
\text { universities, the largest being Beihang University. }\end{array}$} & $\begin{array}{l}\text { Beihang } \\
\text { University }\end{array}$ & 210 & $6 \%$ \\
\hline & $\begin{array}{l}\text { Beijing Institute } \\
\text { of Technology }\end{array}$ & 200 & $4 \%$ \\
\hline \multirow{3}{*}{$\begin{array}{l}\text { CASC and Beihang signed a strategic cooperation } \\
\text { agreement in December } 2018 \text {, in which Beihang's party } \\
\text { secretary thanked CASC for its longstanding support for the } \\
\text { university. }{ }^{81} \text { CASC has historically organized visits for } \\
\text { Beihang students at various CASC laboratories and sent } \\
\text { high-profile experts to teach courses on campus. }{ }^{82}\end{array}$} & $\begin{array}{l}\text { Northwestern } \\
\text { Polytechnical } \\
\text { University }\end{array}$ & 198 & $6 \%$ \\
\hline & $\begin{array}{l}\text { Harbin Institute } \\
\text { of Technology }\end{array}$ & 170 & $4 \%$ \\
\hline & $\begin{array}{l}\text { Nanjing } \\
\text { University of } \\
\text { Science and } \\
\text { Technology }\end{array}$ & 92 & $3 \%$ \\
\hline
\end{tabular}




\begin{tabular}{|c|c|c|c|}
\hline $\begin{array}{l}\text { CEicha Electronics Technology Group (CETC) } \\
\text { 中国电子科技集团 }\end{array}$ & University & $\begin{array}{l}\text { No. of } 2019 \\
\text { Graduates } \\
\text { Recruited by } \\
\text { CETC }\end{array}$ & $\begin{array}{l}\text { Portion of All } \\
\text { Employed } \\
\text { Graduates } \\
\text { Working at } \\
\text { CETC }\end{array}$ \\
\hline $\begin{array}{l}\text { At least 1,370 graduates from leading Chinese universities } \\
\text { took jobs at CETC in } 2019 \text {. Available data indicates that } 669 \\
\text { employees ( } 49 \text { percent) came from five primary feeder } \\
\text { universities, the largest being Northwestern Polytechnical } \\
\text { University. }\end{array}$ & $\begin{array}{l}\text { Northwestern } \\
\text { Polytechnical } \\
\text { University }\end{array}$ & 157 & $5 \%$ \\
\hline \multirow{4}{*}{$\begin{array}{l}\text { NWPU and CETC maintain extensive connections. Since } \\
2005 \text {, affiliates from both entities have published over } 100 \\
\text { research products together, according to data from the China } \\
\text { National Knowledge Infrastructure. CETC also conducts } \\
\text { seminars and various talent training and recruitment programs } \\
\text { at NWPU, } 83 \text { including one in } 2016 \text { that focused on the } \\
\text { evolution of warfare and the effectiveness of mechanized and } \\
\text { informatized warfare. }{ }^{84}\end{array}$} & $\begin{array}{l}\text { Harbin Institute } \\
\text { of Technology }\end{array}$ & 151 & $3 \%$ \\
\hline & $\begin{array}{l}\text { Beijing Institute } \\
\text { of Technology }\end{array}$ & 135 & $3 \%$ \\
\hline & $\begin{array}{l}\text { Naniing } \\
\text { University of } \\
\text { Science and } \\
\text { Technology }\end{array}$ & 122 & $4 \%$ \\
\hline & $\begin{array}{l}\text { University of } \\
\text { Science and } \\
\text { Technology of } \\
\text { China }\end{array}$ & 104 & $4 \%$ \\
\hline
\end{tabular}




\section{$8 \% 8$}

\section{China National Nuclear Corporation} (CNNC)

中国核工业集团公司

At least 209 graduates from leading Chinese universities took jobs at CNNC in 2019. Among our sample, 174 employees (83 percent) came from six primary feeder universities, the largest being Harbin Engineering University.

Aside from shipbuilding, HEU is a leader in Chinese nuclear research. CNNC and HEU in September 2018 signed a strategic cooperation agreement as a means to more quickly and effectively transform HEU's theoretical research into applied research and products. ${ }^{85}$ In addition, HEU and CNNC in January 2019 jointly established the China Nuclear Industry Safety and Simulation Technology Research Institute. ${ }^{86}$

\begin{tabular}{|l|r|r|}
\hline University & $\begin{array}{l}\text { No. of 2019 } \\
\text { Graduates } \\
\text { Recruited by } \\
\text { CNNC }\end{array}$ & $\begin{array}{l}\text { Portion of All } \\
\text { Employed } \\
\text { Graduates } \\
\text { Working at } \\
\text { CNNC }\end{array}$ \\
\hline $\begin{array}{l}\text { Harbin } \\
\text { Engineering } \\
\text { University }\end{array}$ & 66 & $2 \%$ \\
\hline $\begin{array}{l}\text { Xi'an Jiaotong } \\
\text { University }\end{array}$ & 33 & $1 \%$ \\
\hline $\begin{array}{l}\text { Tsinghua } \\
\text { University }\end{array}$ & 29 & $<1 \%$ \\
\hline $\begin{array}{l}\text { Tianin } \\
\text { University }\end{array}$ & 26 & $<1 \%$ \\
\hline $\begin{array}{l}\text { Southeast } \\
\text { University }\end{array}$ & 10 & $<1 \%$ \\
\hline $\begin{array}{l}\text { Harbin Institute } \\
\text { of Technology }\end{array}$ & 10 & \\
\hline
\end{tabular}

\section{K} China North Industries Corporation
(NORINCO)

中国兵器工业集团

At least 318 graduates from leading Chinese universities took jobs at NORINCO in 2019. Available data indicates that 282 employees (89 percent) came from five primary feeder universities, the largest being Beiijing Institute of Technology.

Over the past decade, NORINCO has held several special job fairs exclusively for BIT students. ${ }^{87}$ The two entities also maintain strategic cooperation agreements, such as one signed in 2012 that emphasized BIT's position as the "most important university in China's weapons industry" and ensured that BIT and NORINCO would work together to further R\&D. ${ }^{88}$

\begin{tabular}{|l|r|r|}
\hline University & $\begin{array}{l}\text { No. of 2019 } \\
\text { Graduates } \\
\text { Recruited by } \\
\text { NORINCO }\end{array}$ & $\begin{array}{l}\text { Portion of All } \\
\text { Employed } \\
\text { Graduates } \\
\text { Working at } \\
\text { NORINCO }\end{array}$ \\
\hline $\begin{array}{l}\text { Beijing Institute } \\
\text { of Technology }\end{array}$ & 110 & $2 \%$ \\
\hline $\begin{array}{l}\text { Nanjing } \\
\text { University of } \\
\text { Science and } \\
\text { Technology }\end{array}$ & & \\
\hline $\begin{array}{l}\text { Northwestern } \\
\text { Polytechnical } \\
\text { University }\end{array}$ & 67 & $2 \%$ \\
\hline $\begin{array}{l}\text { Beihang } \\
\text { University }\end{array}$ & 58 & \\
\hline $\begin{array}{l}\text { Harbin } \\
\text { Engineering } \\
\text { University }\end{array}$ & 28 & $1 \%$ \\
\hline
\end{tabular}




\begin{tabular}{|c|c|c|c|c|}
\hline \multirow{3}{*}{\multicolumn{2}{|c|}{$\begin{array}{l}\text { China Shipbuilding Industry Corporation } \\
\text { (CSIC) } \\
\text { 中国船舶重工股份有限公司 } \\
\text { At least } 322 \text { graduates from leading Chinese universities took } \\
\text { jobs at CSIC in } 2019 \text { prior to its merger with CSSC. Available } \\
\text { data indicates that } 281 \text { employees (87 percent) came from five } \\
\text { primary feeder universities. Harbin Engineering University was } \\
\text { the single largest supplier of university graduates to CSIC, } \\
\text { accounting for over half of all recruited employees in our } \\
\text { sample. }\end{array}$}} & University & $\begin{array}{l}\text { No. of } 2019 \\
\text { Graduates } \\
\text { Recruited by } \\
\text { CSIC }\end{array}$ & $\begin{array}{l}\text { Portion of All } \\
\text { Employed } \\
\text { Graduates } \\
\text { Working at } \\
\text { CSIC }\end{array}$ \\
\hline & & \begin{tabular}{|l} 
Harbin \\
Engineering \\
University
\end{tabular} & 172 & $5 \%$ \\
\hline & & \begin{tabular}{|l} 
Dalian \\
University of \\
Technology
\end{tabular} & 31 & $1 \%$ \\
\hline \multicolumn{2}{|c|}{$\begin{array}{l}\text { Harbin Engineering University has maintained long-standing } \\
\text { connections to China's shipbuilding industry. HEU in } 1970 \text { was }\end{array}$} & $\begin{array}{l}\text { Northwestern } \\
\text { Polytechnical } \\
\text { University }\end{array}$ & 31 & $1 \%$ \\
\hline \multirow{3}{*}{\multicolumn{2}{|c|}{$\begin{array}{l}\text { known as the Harbin Shipbuilding Engineering Institute and } \\
\text { was previously under the administration of China State } \\
\text { Shipbuilding Corporation (CSSC), }{ }^{89} \text { which CSIC spun off from } \\
\text { in } 1999 .{ }^{\circ} \text { With respect to autonomy and undersea systems } \\
\text { specifically, Naniing University of Science and Technology has } \\
\text { collaborated closely with CSIC's } 724 \text { Institute. The institute } \\
\text { focuses on intelligent manufacturing and equipment, }{ }^{91} \text { and } \\
\text { claims to "adhere to military-oriented technological } \\
\text { innovation." }\end{array}$}} & $\begin{array}{l}\text { Xi'an Jiaotong } \\
\text { University }\end{array}$ & 26 & $1 \%$ \\
\hline & & $\begin{array}{l}\text { Harbin Institute } \\
\text { of Technology }\end{array}$ & 21 & $<1 \%$ \\
\hline & & & & \\
\hline
\end{tabular}

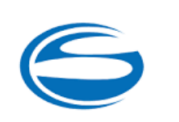

\section{China South Industries Group Corporation (CSGC) \\ 中国兵器装备集团公司}

At least 87 graduates from leading Chinese universities took jobs at CSGC in 2019. Among our sample, Harbin Engineering University is overwhelmingly the largest feeder school, with HEU graduates representing 75 (86 percent) of the employees recruited that year.

The authors could not find any information to indicate deliberate overtures between HEU and CSGC. However, some of CSGC's subsidiaries are headquartered in nearby cities in Heilongiiang province, and their local job postings may appeal to HEU graduates. ${ }^{93}$

\begin{tabular}{|l|l|l|}
\hline University & $\begin{array}{l}\text { No. of 2019 } \\
\text { Graduates } \\
\text { Recruited by } \\
\text { CSGC }\end{array}$ & $\begin{array}{l}\text { Portion of All } \\
\text { Employed } \\
\text { Graduates } \\
\text { Working at } \\
\text { CSGC }\end{array}$ \\
\hline $\begin{array}{l}\text { Harbin } \\
\text { Engineering } \\
\text { University }\end{array}$ & 75 & $2 \%$ \\
\hline $\begin{array}{l}\text { All Other } \\
\text { Universities }\end{array}$ & 12 & N/A \\
\hline
\end{tabular}




\begin{tabular}{|c|c|c|c|}
\hline $\begin{array}{l}\text { China State Shipbuilding Corporation } \\
\text { (CSSC) } \\
\text { 中国船舶集团有限公司 }\end{array}$ & University & $\begin{array}{l}\text { No. of } 2019 \\
\text { Graduates } \\
\text { Recruited by } \\
\text { CSSC }\end{array}$ & $\begin{array}{l}\text { Portion of } A / / \\
\text { Employed } \\
\text { Graduates } \\
\text { Working at } \\
\text { CSSC }\end{array}$ \\
\hline $\begin{array}{l}\text { At least } 177 \text { graduates from leading Chinese universities took } \\
\text { jobs at CSSC in } 2019 \text {. However, data on graduates bound } \\
\text { for CSSC was only available for five of the } 45 \text { universities } \\
\text { selected for this study. All five feeder universities are shown to } \\
\text { the right, Nanjing University of Science and Technology being } \\
\text { the largest. }\end{array}$ & $\begin{array}{l}\text { Naniing } \\
\text { University of } \\
\text { Science and } \\
\text { Technology }\end{array}$ & 54 & $2 \%$ \\
\hline \multirow{4}{*}{$\begin{array}{l}\text { In } 2017,30 \text { individuals from NJUST were permitted to visit } \\
\text { CSSC's } 724 \text { Institute for tours and seminars. }{ }^{94} \text { NJUST and the } \\
724 \text { Institute have also published research together, including } \\
\text { a } 2017 \text { piece entitled "Research on the legal guarantee } \\
\text { mechanism of military-civil fusion in military research institutes" } \\
\text { (军工科研院所军民融合法律保障机制研究). }{ }^{95}\end{array}$} & $\begin{array}{l}\text { Shanghai } \\
\text { Jiaotong } \\
\text { University }\end{array}$ & 36 & $1 \%$ \\
\hline & $\begin{array}{l}\text { Beijing Institute } \\
\text { of Technology }\end{array}$ & 31 & $1 \%$ \\
\hline & $\begin{array}{l}\text { Beihang } \\
\text { University }\end{array}$ & 30 & $1 \%$ \\
\hline & $\begin{array}{l}\text { Huazhong } \\
\text { University of } \\
\text { Science \& } \\
\text { Technology }\end{array}$ & 26 & $1 \%$ \\
\hline
\end{tabular}

\section{Commercial Aircraft Corporation of China comac (COMAC) 中国商用飞机有限公司}

At least 280 graduates from leading Chinese universities took jobs at COMAC in 2019. Among our sample, 261 employees (93 percent) came from six universities, the largest being Beihang University.

Beihang University and COMAC have operated under a strategic cooperation agreement for talent training since 2009.96 In 2019, the two organizations inaugurated two separate labs, including the Large Aircraft Flight Control/Hydraulic/Landing Gear Joint Laboratory (大飞机飞 控/液压/起落架联合实验室) and the Large Aircraft Innovation Valley Joint Laboratory (大飞机创新谷联合实验 室). ${ }^{97}$

\begin{tabular}{|l|l|l|}
\hline University & $\begin{array}{l}\text { No. of 2019 } \\
\text { Graduates } \\
\text { Recruited by } \\
\text { COMAC }\end{array}$ & $\begin{array}{l}\text { Portion of All } \\
\text { Employed } \\
\text { Graduates } \\
\text { Working at } \\
\text { COMAC }\end{array}$ \\
\hline $\begin{array}{l}\text { Beihang } \\
\text { University }\end{array}$ & 137 & $4 \%$ \\
\hline Tongii University & 37 & $1 \%$ \\
\hline $\begin{array}{l}\text { Shanghai } \\
\text { Jiaotong } \\
\text { University }\end{array}$ & 34 & $<1 \%$ \\
\hline $\begin{array}{l}\text { Beijing Institute } \\
\text { of Technology }\end{array}$ & 31 & $<1 \%$ \\
\hline $\begin{array}{l}\text { Harbin Institute } \\
\text { of Technology }\end{array}$ & 22 & $<1 \%$ \\
\hline
\end{tabular}




\begin{tabular}{|c|c|c|c|}
\hline $\begin{array}{l}\text { People's Liberation Army } \\
\text { (PLA) Forces }\end{array}$ & University & $\begin{array}{l}\text { No. of } 2019 \\
\text { Graduates } \\
\text { Who Joined } \\
\text { the PLA }\end{array}$ & $\begin{array}{l}\text { Portion of All } \\
\text { Employed } \\
\text { Graduates } \\
\text { Working for } \\
\text { the PLA }\end{array}$ \\
\hline $\begin{array}{l}\text { At least 1,487 students at leading Chinese universities joined } \\
\text { the PLA directly upon graduating in } 2019 \text {. }\end{array}$ & $\begin{array}{l}\text { Lanzhou } \\
\text { University }\end{array}$ & 128 & $3 \%$ \\
\hline \multirow{2}{*}{$\begin{array}{l}28 \text { of the } 29 \text { universities for which data was available reported } \\
\text { one or more graduates joining the PLA. Among our sample, the } \\
\text { top five source universities produced } 512 \text { PLA officers ( } 26 \\
\text { percent), the largest being Lanzhou University. }\end{array}$} & Jilin University & 109 & $2 \%$ \\
\hline & $\begin{array}{l}\text { Harbin } \\
\text { Engineering } \\
\text { University }\end{array}$ & 105 & $3 \%$ \\
\hline \multirow{3}{*}{$\begin{array}{l}\text { Since 2019, Lanzhou University has been party to a } \\
\text { cooperation agreement with the PLA Army Frontier and Coastal } \\
\text { Defense College. }{ }^{98} \text { It is located in a strategically important } \\
\text { region in northwestern China, and tends to produce graduates } \\
\text { who join the military. In } 2016 \text {, Lanzhou University launched a } \\
\text { Rocket Force Silk Road Scholarship (火箭军丝路奖助学金) } \\
\text { program, which fully funds } 100 \text { students at the university. }{ }^{99} \text { The } \\
\text { PLA also holds frequent recruitment drives at the university. }{ }^{100}\end{array}$} & $\begin{array}{l}\text { Harbin Institute } \\
\text { of Technology }\end{array}$ & 88 & $2 \%$ \\
\hline & $\begin{array}{l}\text { Northwestern } \\
\text { Polytechnical } \\
\text { University }\end{array}$ & 82 & $2 \%$ \\
\hline & & & \\
\hline
\end{tabular}

\begin{tabular}{|c|c|c|c|}
\hline $\begin{array}{l}\text { China Academy of Engineering Physics } \\
\text { (CAEP) } \\
\text { 中国工程物理研究院 }\end{array}$ & University & $\begin{array}{l}\text { No. of } 2019 \\
\text { Graduates } \\
\text { Employed }\end{array}$ & $\begin{array}{l}\text { Portion of All } \\
\text { Employed } \\
\text { Graduates } \\
\text { Working at } \\
\text { CAEP }\end{array}$ \\
\hline \multirow{2}{*}{$\begin{array}{l}\text { Founded in } 1958,{ }^{101} \text { the China Academy of Engineering } \\
\text { Physics is China's leading nuclear weapons lab. }{ }^{102} \text { It is } \\
\text { headquartered in Mianyang, China, }{ }^{103} \text { and employs } 24,000 \\
\text { people. }{ }^{104}\end{array}$} & $\begin{array}{l}\text { Xi'an Jiaotong } \\
\text { University }\end{array}$ & 24 & $1 \%$ \\
\hline & $\begin{array}{l}\text { University of } \\
\text { Science and } \\
\text { Technology of } \\
\text { China }\end{array}$ & 20 & $1 \%$ \\
\hline \multirow{2}{*}{$\begin{array}{l}\text { At least } 92 \text { graduates from leading Chinese universities took } \\
\text { positions at CAEP in } 2019 \text {. Only six universities published } \\
\text { data about how many of their graduates worked for CAEP; all } \\
\text { of them are featured to the right. }\end{array}$} & $\begin{array}{l}\text { Harbin Institute } \\
\text { of Technology }\end{array}$ & 19 & $<1 \%$ \\
\hline & $\begin{array}{l}\text { Zhejiang } \\
\text { University }\end{array}$ & 16 & $<1 \%$ \\
\hline \multirow{3}{*}{$\begin{array}{l}\text { CAEP has been on the U.S. Department of Commerce's } \\
\text { Bureau of Industry and Security Entity List since } 2012 \text {, and } \\
\text { several of its affiliates have been added since. }{ }^{105} \text { In July } 2016 \text {, } \\
\text { CAEP signed a strategic cooperation agreement with Xi'an } \\
\text { Jiaotong University to "jointly carry out scientific research and } \\
\text { innovation and share advantageous resources." }{ }^{106} \text { In } 2020 \text {, } \\
\text { staff at XJTU launched three new research projects with the } \\
\text { China International Nuclear Fusion Energy Program. }{ }^{107}\end{array}$} & $\begin{array}{l}\text { Beihang } \\
\text { University }\end{array}$ & 8 & $<1 \%$ \\
\hline & \begin{tabular}{|l|} 
Tianjin \\
University
\end{tabular} & 5 & $<1 \%$ \\
\hline & & & \\
\hline
\end{tabular}




\section{Endnotes}

' Ros Krasny, "GOP Senator Says Don't Let Chinese Students Study STEM in U.S.," Bloomberg, April 26, 2020, https://www.bloomberg.com/news/articles/2020-0426/gop-senator-says-don-t-let-chinese-students-study-stem-in-u-s.

${ }^{2}$ See analysis by Glenn Tiffert, "Global Engagement: Rethinking Risk in the Research Enterprise," Hoover Institution, July 30, 2020, https://www.hoover.org/globalengagement-rethinking-risk-research-enterprise; Alex Joske, "The China Defence Universities Tracker" (Australian Strategic Policy Institute, November 2019),

https://www.aspi.org.au/report/china-defence-universities-tracker; and Elizabeth Redden, "New Restrictions for Chinese Students With Military University Ties," Inside Higher Ed, May 29, 2020, https://www.insidehighered.com/news/2020/05/29/us-plans-cancel-visasstudents-ties-universities-connected-chinese-military.

3 "Proclamation on the Suspension of Entry as Nonimmigrants of Certain Students and Researchers from the People's Republic of China," Executive Office of the President, May 29, 2020, https://www.whitehouse.gov/presidential-actions/proclamation-suspensionentry-nonimmigrants-certain-students-researchers-peoples-republic-china/.

4 "New Chinese Double First Class University Plan Released," Charlesworth Author Services, October 3, 2017, https://cwauthors.com/article/double-first-class-list.

${ }^{5}$ Shengbing Li, "From 985 to World Class 2.0: China's Strategic Move," Inside Higher Ed, February 7, 2018, https://www.insidehighered.com/blogs/world-view/985-world-class20-chinas-strategic-move.

${ }^{6}$ This column indicates institutions that are on the U.S. Bureau of Industry and Security's Entity List, or which are subject to other sanctions. See Bureau of Industry and Security, Supplement No. 4 to Part 744 - ENTITY LIST (Washington, DC: Department of Commerce, 2020), https://www.bis.doc.gov/index.php/documents/regulations-docs/2326-supplement-no4-to-part-744-entity-list-4/file; and "Imposition of Nonproliferation Measures Against Chinese and North Korean Entities, Including Ban on U.S. Government Procurement," Department of State, July 3, 2003, https://www.federalregister.gov/documents/2003/07/03/03-16938/imposition-ofnonproliferation-measures-against-chinese-and-north-korean-entities-including-ban-on.

7 "China Aviation Engine Group Co., Ltd. held its inaugural meeting in Beijing" [中国航空发 动机集团有限公司在京召开成立大会]，Ministry of Industry and Information Technology， August 2016, https://web.archive.org/web/20180114042209/http://www.miit.gov.cn/n1 146290/ n1146402/n1 146440/c5223514/content.html.

8 "China launches state-owned aircraft engine maker: state media," Reuters, August 28, 2016, https://www.reuters.com/article/us-china-aviation-engines/china-launches-stateowned-aircraft-engine-maker-state-media-idUSKCN1 1305R. 
9 "Group Profile" [集团简介], Aviation Industry Corporation of China, accessed July 2020, https://archive.vn/QPIQk.

${ }^{10}$ In 1999 AVIC was split into China Aviation Industry Corporation I and China Aviation Industry Corporation II. The two entities were merged back together in November 2008. For more information, see "Aviation Industry Corporation of China, Ltd. is Established on Nov 6, 2008," State-Owned Assets Supervision and Administration Commission, November 6, 2019, https://archive.vn/UrztX.

11 "Group Profile," Aviation Industry Corporation of China.

12 "Group Profile," Aviation Industry Corporation of China.

${ }^{13}$ CASC and CASIC's original predecessor was the Fifth Institute of the Ministry of National Defense, established in 1956. For more information, see Tate Nurkin, Kelly Bedard, James Clad, Cameron Scott, and Jon Grevat, "China's Advanced Weapons Systems," Jane's, May 12, 2018, https://www.uscc.gov/sites/default/files/Research/Jane's\%20by\%20lHS\%20Markit Chi na's\%20Advanced\%20Weapons\%20Systems.pdf.

14 "Group Profile" [集团简介], China Aerospace Science and Technology Corporation, accessed July 2020, https://archive.vn/NFPPt.

15 "Group Profile," China Aerospace Science and Technology Corporation.

${ }^{16}$ CASC and CASIC's original predecessor was the Fifth Institute of the Ministry of National Defense, established in 1956. For more information, see: https://archive.vn/pasP6.

17 "China Aerospace Science \& Technology," Fortune Global 500, accessed July 2020, https://fortune.com/global500/2019/china-aerospace-science-technology/.

18 "Group Introduction" [集团介绍], China Electronics Technology Group Corporation, accessed July 2020, https://archive.vn/keoGp.

19 "Group Introduction," China Electronics Technology Group Corporation.

20 "Group Introduction," China Electronics Technology Group Corporation.

21 "Group Introduction" [集团介绍], China National Nuclear Corporation, accessed July 2020, https://archive.vn/SbNaP.

22 "Group Introduction," China National Nuclear Corporation.

23 "China North Industries (NORINCO)," Nuclear Threat Initiative, September 2009, https://www.nti.org/learn/facilities/49/. 
24 "Group Profile" [集团简介], China North Industries Group Corporation, Limited, accessed July 2020, https://archive.vn/rE902.

25 "Group Profile," China North Industries Group Corporation, Limited.

26 "China Shipbuilding Industry Corporation 2019 Annual Report"

[中国船舶重工股份有限公司 2019年年度报告], China Shipbuilding Industry

Corporation, accessed July 2020,

http://static.sse.com.cn/disclosure/listedinfo/announcement/c/2020-04-

29/601989_20200429_2.pdf.

27 "China Shipbuilding Industry," Fortune Global 500, accessed July 2020,

https://fortune.com/global500/2019/china-shipbuilding-industry/.

28 "Our Business" [我们的企业], China State Shipbuilding Corporation, Limited, accessed July 2020, https://archive.vn/A3RiM.

29 "Our Business," China State Shipbuilding Corporation, Limited.

30 "Our Business," China State Shipbuilding Corporation, Limited.

31 "Company Profile" [公司简介], Commercial Aircraft Corporation of China, accessed October 2020, https://archive.vn/5RyfW.

32 "Talent Concept," Commercial Aircraft Corporation of China, accessed October 2020, https://archive.vn/PVcPd.

33 "Company Profile," Commercial Aircraft Corporation of China.

34 "Our Business" [我们的企业], China State Shipbuilding Corporation, accessed October 2020, https://archive.vn/V7ipk.

35 "Career Prospects for Arizona Grads," University of Arizona, accessed July 2020, https://career.arizona.edu/career-prospects-high-arizona-grads.

36 “2019 Annual Report on Graduate Employment Quality" [2019 年毕业生就业质量年 度报告北京航空航天大学] (Beihang University of Aeronautics and Astronautics, December 2019), 14, https://web.archive.org/web/20200601171615/http://www.gaokzx.com/Fup/docu ment/202001/01-03 115648-10025.pdf.

37 “2018 Annual Report on Graduate Employment Quality” [2018 年毕业生就业质量年 度报告] (Harbin Engineering University, 2018), https://web.archive.org/web/20200721135919/http://xxgk.hrbeu.edu.cn/ upload/a rticle/files/9b/79/7cc53aed4d159840beb2fb597176/1fa6df55-6e61-4ac7-a3bee59223a0b984.pdf. 
38 "Imposition of Nonproliferation Measures Against Chinese and North Korean Entities, Including Ban on U.S. Government Procurement," Department of State, July 3, 2003, https://www.federalregister.gov/documents/2003/07/03/03-16938/imposition-ofnonproliferation-measures-against-chinese-and-north-korean-entities-including-ban-on.

${ }^{39}$ Alex Joske, "The China Defence Universities Tracker" (Australian Strategic Policy Institute, November 25, 2019), https://www.aspi.org.au/report/china-defence-universities-tracker.

40 "Build a new type of military talent training base" [建设新型军事人才培养基地], Dalian Science and Technology Bureau, June 10, 2004, https://archive.vn/Ali9E.

${ }_{41}$ "Build a new type of military talent training base."

42 "Tianjin University was named 'Advanced Unit of National Defense Education"" [天津大学被评为 “国防教育先进单位”], Tianjin University, March 31, 2016, https://archive.vn/iHKOK.

43 "Tianjin University and the National Defense Technology Innovation Research Institute of the Academy of Military Sciences jointly established a transformative human-computer interaction technology innovation joint laboratory"

[天津大学与军事科学院国防科技创新研究院共建变革性人机交互技术创新联合实 验室], Tianjin University, October 18, 2018, https://archive.vn/OHx1H.

${ }^{44}$ Beyond the Seven Sons, some U.S. and foreign companies have partnered directly with PLA military academies. For example, the U.S. chip design company Synopsys hosted an IC and FPGA design training session at the PLA National University of Defense Technology in 2018. See "Brief Introduction of Industry-University Cooperation Collaborative Education Projects," Ministry of Education of the People's Republic of China, 2018, https://rb.gy/gl mipq (Batch 1); https://rb.gy/vapzy3 (Batch 2).

45 "2018 Microsoft Research Asia-Ministry of Education Industry-University Cooperation Collaborative Education Project Application Guidelines" [2018 年微软亚洲研究院-教育 部产学合作协同育人项目申报指南], Microsoft Research Asia, 2018, https://web.archive.org/web/20201015180833/https://www.msra.cn/zh$\mathrm{cn} /$ connections/academic-programs/academia-industry-cooperation-2018-1.

46 "2018 Microsoft Research Asia-Ministry of Education Industry-University Cooperation Collaborative Education Project Application Guidelines."

47 "Harbin Institute of Technology Machine Intelligence and Translation Research Office" [哈 尔滨工业大学机器智能与翻译研究室], Harbin Institute of Technology, 2017, https://web.archive.org/web/20201015153018/http://mitlab.hit.edu.cn/9179/list.ht m. 
${ }^{48}$ Forced technology transfer has been a longstanding grievance of U.S. and European companies doing business in China. See Lee G. Branstetter, "China's Forced Technology Transfer Problem-And What to Do About It" (Peterson Institute for International Economics, June 2018), https://www.piie.com/system/files/documents/pb18-13.pdf; and Don Weinland, "European companies forced to hand tech to China," Financial Times, May 20, 2019, https://www.ft.com/content/f2f4dca0-7abc-1 le9-81d2-f785092ab560.

${ }^{49}$ Sean O'Connor, "How Chinese Companies Facilitate Technology Transfer from the United States," U.S.-China Economic and Security Review Commission, May 6, 2019, https://www.uscc.gov/sites/default/files/Research/How\%20Chinese\%20Companies\%2 OFacilitate\%20Tech\%20Transfer\%20from\%20the\%20US.pdf.

50 "Letter of the Higher Education Department of the Ministry of Education on the publication of the guidelines for the application of industry-university cooperation collaborative education projects supported by enterprises (the first batch of 2018)" [教育部高等教育司 关于公布有关企业支持的产学合作协同育人项目申报指南（2018 年第一批）的函 ], Ministry of Education of the People's Republic of China, 2018, https://web.archive.org/web/20201002202843/http://www.moe.gov.cn/s78/A08/t ongzhi/201805/†20180503 334906.html.

51 "The National Medium-and Long-Term Program for Science and Technology Development (2006-2020)," State Council of the PRC, translated by the International Telecommunication Union, accessed October 2020, https://www.itu.int/en/ITU-

D/Cybersecurity/Documents/National Strategies Repository/China 2006.pdf.

52 "Introduction of Industry-University Cooperation Collaborative Education Projects" [产学

合作协同育人项目介绍], Ministry of Education Industry-University Cooperation

Collaborative Education Project Platform, accessed November 2020,

https://web.archive.org/web/20200805141410/http://123.57.250.226/Professional ProjectWebsite/html/index.html.

${ }^{53}$ See documents titled "Brief Introduction of Industry-University Cooperation Collaborative Education Projects," which are published on MOE's website biannually: 2018 Batch 1, https://rb.gy/g1 mipq; 2018 Batch 2, https://rb.gy/uapzy3; 2019 Batch 1, https://rb.gy/e662re; and 2019 Batch 2, https://rb.gy/wapbyd.

54 "Beiijing Institute of Technology and IBM signed a contract to jointly build the 'IBM Mainframe Excellence Center'" [北京理工大学与 IBM 公司签约共建“IBM 主机卓越中 心"], Beijing Institute of Technology, April 2014, https://web.archive.org/web/20201015140641/http://www.bit.edu.cn/xww/zhxw/ 100498.htm.

55 "Beiijing Institute of Technology and IBM signed a contract to jointly build the 'IBM Mainframe Excellence Center.'" 
56 "IBM joins hands with universities to promote 'new engineering construction' and build a new ecosystem of education cooperation" [IBM 携手高校推进 “新工科建设” 共建教育 合作新生态], IBM China (Sohu post), April 11, 2018, https://archive.vn/UgaAt\#selection-913.172-913.386.

57 "IBM joins hands with universities to promote 'new engineering construction' and build a new ecosystem of education cooperation."

58 "About Us" [关于我们], IBM China, accessed November 2020, https://web.archive.org/web/20201106211202/https://www-

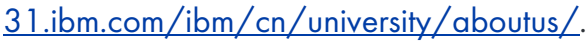

59 "About Us" [关于我们], IBM China, accessed November 2020， https://web.archive.org/web/20201106211202/https://www$31 . \mathrm{ibm} . \mathrm{com} / \mathrm{ibm} / \mathrm{cn} /$ university/aboutus/.

60 "Harbin Institute of Technology Machine Intelligence and Translation Research Office" [哈 尔滨工业大学机器智能与翻译研究室], Harbin Institute of Technology, 2017, https://web.archive.org/web/20201015153018/http://mitlab.hit.edu.cn/9179/list.ht m.

61 "Harbin Institute of Technology Machine Intelligence and Translation Research Office."

62 "Harbin Institute of Technology Ministry of Education-Microsoft Key Laboratory" [哈工大 语言语音教育部-微软重点实验室], Daqing Science and Technology Innovation and Entrepreneurship Shared Service Platform, accessed October 2020, https://web.archive.org/web/20201015143130/http://www.dqkyw.org.cn/zone 78 91505/lab/33.html.

${ }^{63}$ "Harbin Institute of Technology Ministry of Education-Microsoft Key Laboratory."

${ }^{64}$ MSRA continues to carry out cooperative training programs for a wide range of Chinese universities. In 2018, more than a quarter of MSRA's cooperative training projects were with Seven Sons universities. See "2018 Microsoft Research Asia-Ministry of Education IndustryUniversity Cooperation Collaborative Education Project (first batch)" [2018 年微软亚洲研 究院-教育部产学合作协同育人项目（第一批）], Microsoft Research Asia, accessed October 2020, https://web.archive.org/web/20201015180833/https://www.msra.cn/zh$\mathrm{cn} /$ connections/academic-programs/academia-industry-cooperation-2018-1. 
${ }^{65}$ In 2018 and 2019, Microsoft Research Asia hosted a teacher training session at HIT entitled "New Artificial Intelligence in Engineering Education Teacher Workshop Practice (Phase I)" [新工科人工智能教育实践师资研讨会（第一期 ) ] and a curriculum development workshop entitled "Natural Language Processing' Course Construction" ["自 然语言处理” 课程建设]. See “Brief Introduction of Industry-University Cooperation Collaborative Education Projects," Ministry of Education of the People's Republic of China.

66 "2018 Microsoft Research Asia-Ministry of Education Industry-University Cooperation Collaborative Education Project (first batch)," Microsoft Research Asia, accessed October 2020.

67 "Harbin Engineering University and Texas Instruments Pocket Laboratory Cooperative Innovation Base was inaugurated and established" [哈尔滨工程大学与美国德州仪器口 袋实验室协同创新基地揭牌成立], Harbin Engineering University School of Information and Communication Engineering, July 2015, https://archive.vn/IcSZc.

${ }^{68} \mathrm{Jin}$ Sheng, “Pocket Lab is fully open" [口袋实验室全面开放], Harbin Engineering University, July 16, 2015, https://archive.vn/pEprM.

${ }^{69}$ The Tl projects at Harbin Engineering University aided in curriculum development, including "Electronic Innovation Design and Practice Open Class and Platform Development" [电子创新设计与实践公开课及平台开发] and “TI Operational Amplifier Typical Circuit Design and Course Research" [TI 运算放大器典型电路设计与课程研究].

70 "Pocket Lab is fully open."

${ }^{71}$ Bethany Allen-Ebrahimian and Zach Dorfman, "Defense Department produces list of Chinese military-linked companies," Axios, June 24, 2020, https://www.axios.com/defense-department-chinese-military-linked-companies856b9315-48d2-4aec-b932-97b8f29a4d40.html.

${ }^{72}$ Concerns Over Nations Funding University Campus Institutes in the United States (CONFUCIUS) Act, S 939, 11 th Cong. (2019), https://www.congress.gov/bill/116thcongress/senate-bill/939.

73 "Tsinghua University," "Peking University," and "Zhejiang University," Australian Strategic Policy Institute, November 2019, https://unitracker.aspi.org.au/universities/tsinghuauniversity/; https://unitracker.aspi.org.au/universities/peking-university/; and https://unitracker.aspi.org.au/universities/zhejiang-university/. 
${ }^{74}$ Researchers at China's elite universities frequently collaborate with U.S. co-authors. Respectively, 44 percent, 35 percent, and 42 percent of publications by authors at Tsinghua, Peking, and Zhejiang University are written with international coauthors, most of whom are in the United States. See "Tsinghua University," "Peking University," and "Zhejiang University," Nature Index, May 2020, https://www.natureindex.com/institutionoutputs/china/tsinghua-university/513906ba34d6b65e6a000049; https://www.natureindex.com/institution-outputs/china/peking-universitypku/5139072d34d6b65e6a002146; and https://www.natureindex.com/institutionoutputs/china/zhejiang-university-zju/5139072d34d6b65e6a002144.

75 "Double First-Class university and discipline list policy update," Australian Department of Education, Skills, and Employment, December 14, 2017, https://internationaleducation.gov.au/International-network/china/PolicyUpdatesChina/Pages/Double-First-Class-university-and-discipline-list-policy-update.aspx.

76 "Beihang alumni Cao Jianguo and Li Fangyong were appointed as Chairman and General Manager of China Aviation Engine Group" [北航校友曹建国、李方勇被任命为 中国航空发动机集团董事长、总经理], Beihang University, March 2016， https://archive.vn/oAf35.

77 “Introduction to the 'Two Academies'” [“两院”介绍], Beihang University, accessed October 2020, https://archive.vn/hfRv8.

78 "Xi'an University of Technology holds the signing ceremony of 'AVIC Scholarship'" [西工大举行 “中航工业奖学金” 签约仪式], Xi'an Jiaotong University, September 30, 2016, https://archive.vn/TRSOl.

79 "AVIC and Aviation Industry and Northwestern Polytechnical University held a symposium in Beijing" [航空工业与西北工业大学在京召开座谈交流会], Aviation Industry Corporation of China, June 2, 2020, https://archive.vn/7Jcll.

80 "The signing ceremony and inauguration ceremony of the 'Missile Aeroelastic Technology Joint Laboratory' between our school and the Second General Design Department of the Second Research Institute of China Aerospace Science and Industry Corporation were held" [我校与中国航天科工集团第二研究院第二总体设计部“导弹气动弹性技术联合实验 室" 签约暨揭牌仪式举行], Beihang University, November 2012, https://archive.vn/1 qsiA.

81 "Beihang University and China Aerospace Science and Technology Corporation signed a comprehensive strategic cooperation agreement"

[北航与中国航天科技集团签署全面战略合作协议], Beihang University, December 3， 2018, https://archive.vn/ek5yz. 
82 "Yuan Jie teaches an open class at Beihang University"

[袁洁在北京航空航天大学讲授公开课], China Aerospace Science and Technology Corporation, December 13, 2019, https://archive.vn/OHK9d.

${ }^{83}$ For example, see "Introduction to the 43rd Research Institute of China Electronics Technology Group Corporation" [中国电子科技集团公司第 43 研究所简介], Northwestern Polytechnical University, April 2013, https://archive.vn/KInmD; "Our school visited the 28th Research Institute of China Electronics Technology Group Corporation"

[我校走访中国电子科技集团公司第二十八研究所], Northwestern Polytechnical University, February 22, 2019, https://archive.vn/B4mcl; "Qiao Wensheng, deputy chief engineer of the Tenth Research Institute of China Electronics Technology Group Corporation, visited our school for exchanges" [中国电子科技集团公司第十研究所乔文昇副总工程 师一行来校交流], Northwestern Polytechnical University, May 2014, https://archive.vn/oc 1Zm.

84 "The Chief Scientist of China Electronics Technology Group, the Army, is a guest in the lecture hall of famous soaring experts" [中国电子科技集团首席科学家陆军做客朝翔名 家讲堂], Northwest Polytechnical University, March 21, 2016, https://archive.vn/JFIIW.

85 "China National Nuclear Corporation and Harbin Engineering University signed a joint construction agreement" [中核集团与哈尔滨工程大学签订共建协议], China National Nuclear Corporation, September 2018, http://archive.vn/oRHIW.

86 "China National Nuclear Corporation joins hands with Harbin Engineering to create a world-class innovation consortium" [中核集团携手哈工程打造国际一流创新联合体], China National Nuclear Corporation, January 2019, http://archive.fo/MSp1L; "Harbin Engineering University," Australian Strategic Policy Institute, November 2019, https://unitracker.aspi.org.au/universities/harbin-engineering-university/.

${ }^{87}$ For example, see "BIT holds a special job fair for China North Industries Group" [北理工举办中国兵器工业集团专场招聘会], Beijing Institute of Technology, September 2016, https://archive.vn/05bPO; and "China North Industries Group Special Job Fair" [中 国兵器工业集团专场招聘会], Beiijing Institute of Technology, October 2010, https://archive.vn/pFRet.

88 "China North Industries Group Corporation-Beijing Institute of Technology joins hands in collaborative innovation" [中国兵器工业集团公司-

北京理工大学携手开展协同创新工作], Beijing Institute of Technology, February 2012， https://archive.vn/BrRqs.

${ }^{89}$ Glenn Tiffert, "Global Engagement: Rethinking Risk in the Research Enterprise," Hoover Institution, July 2020.

90 "Our Business" [我们的企业], China State Shipbuilding Corporation, Limited, accessed July 2020, https://archive.vn/A3RiM. 
91 "Company Introduction" [企业介绍], 724 Institute of China State Shipbuilding Corporation, accessed August 2020, https://archive.vn/N5T4J.

92 "Notice on Visiting and Exchange of China Shipbuilding 724 Research Institute" [关于赴 中船 724 研究所参观交流的通知], Nanjing University of Science and Technology, https://archive.vn/sLHvM.

93 "Recruitment," China South Industries Group Corporation, accessed August 2020, http://archive.vn/aOnOz.

94 "Notice on Visiting and Exchange of China Shipbuilding 724 Research Institute," Nanjing University of Science and Technology.

${ }^{95}$ Xu Lin, Gao Shenghan, and Xiao Yihong, "Research on the legal guarantee mechanism of military-civilian integration in military research institutes"

[军工科研院所军民融合法律保障机制研究], Modern Economic Information [现代经济信息],

https://xueshu.baidu.com/usercenter/paper/show?paperid=09e569acfd5e2f2b4e8bd5 $645175 \mathrm{~d} 36 \mathrm{c}$.

96 "Our school and Commercial Aircraft Corporation of China signed a school-enterprise cooperation agreement on talent training" [我校与中国商用飞机有限责任公司签署人才 培养校企合作协议书], Beihang University, April 2009, https://archive.vn/RsDnU.

97 "Inauguration of the Joint Laboratory of Additive Technology Joint Laboratory of the Large Aircraft Innovation Valley jointly established by COMAC and Beihang" [中国商飞与北航 联合共建的大飞机创新谷联合实验室一增材技术联合实验室揭牌], Beihang University, June 2019, https://archive.vn/axgEK.

98 "Lanzhou University and the Chinese People's Liberation Army Frontier and Coastal Defense College signed a cooperation agreement"

[兰州大学与中国人民解放军陆军边海防学院签订合作协议], Lanzhou University, November 2019, http://archive.vn/7nEYj.

99 "The donation and award ceremony of the 'Rocket Army Silk Road Scholarship' of the 96351 Unit of the Chinese People's Liberation Army was held in Lanzhou University" [中国 人民解放军 96351 部队“火箭军丝路助学金”捐赠暨颁奖仪式在兰州大学举行]， Lanzhou University, December 2016, http://archive.vn/nkic4.

100 "Recruitment brochure for a certain unit of the Chinese People's Liberation Army" [中国人 民解放军某部队招聘简章], Lanzhou University, March 2020, http://archive.vn/dDC2t.

101 "China Academy of Engineering Physics," OMICS International, accessed August 2020, https://www.omicsonline.org/universities/China Academy of Engineering Physics/. 
102 "Chinese Academy of Engineering Physics," Australian Strategic Policy Institute, November 2019, https://unitracker.aspi.org.au/universities/chinese-academy-ofengineering-physics/.

103 John Pike, "Chinese Academy of Engineering Physics (CAEP)," Federation of American Scientists, May 2000, https://fas.org/nuke/guide/china/facility/mianyang.htm.

104 "Chinese Academy of Engineering Physics," Australian Strategic Policy Institute.

105 "Addition of Certain Persons to the Entity List; Removal of Person From the Entity List Based on Removal Request; and Implementation of Entity List Annual Review Changes," Bureau of Industry and Security, September 19, 2012,

https://www.federalregister.gov/documents/2012/09/19/2012-22952/addition-ofcertain-persons-to-the-entity-list-removal-of-person-from-the-entity-list-based-on.

106 "Xi'an Jiaotong University and China Academy of Engineering Physics signed a strategic cooperation agreement" [西安交通大学与中国工程物理研究院签署战略合作协议], Xi'an Jiaotong University, July 2016, http://archive.vn/cgtuk.

107 "The list of projects that need to submit the 2019 project implementation report and the 2020 project implementation plan" [需提交 2019 年度项目执行情况报告和 2020 年度 项目执行计划的项目清单], China International Nuclear Fusion Energy Program Execution Center, accessed August 2020, https://web.archive.org/web/20200813151333/http://www.iterchina.cn/upload/2b d9769b-aa91-41b8-945a-dcd2fb6c 1515/aaf221bl-30a0-40a7-b723-

f4f407872548.pdf. 